\title{
Catalytic Conversion of Methane to Methanol Using Cu-Zeolites
}

\author{
Evalyn Mae C. Alayon, Maarten Nachtegaal, Marco Ranocchiari, and Jeroen A. van Bokhoven
}

\begin{abstract}
The conversion of methane to value-added liquid chemicals is a promising answer to the imminent demand for fuels and chemical synthesis materials in the advent of a dwindling petroleum supply. Current technology requires high energy input for the synthesis gas production, and is characterized by low overall selectivity, which calls for alternative reaction routes. The limitation to achieve high selectivity is the high $\mathrm{C}-\mathrm{H}$ bond strength of methane. High-temperature reaction systems favor gas-phase radical reactions and total oxidation. This suggests that the catalysts for methane activation should be active at low temperatures. The enzymatic-inspired metal-exchanged zeolite systems apparently fulfill this need, however, methanol yield is low and a catalytic process cannot yet be established. Homogeneous and heterogeneous catalytic systems have been described which stabilize the intermediate formed after the first $\mathrm{C}-\mathrm{H}$ activation. The understanding of the reaction mechanism and the determination of the active metal sites are important for formulating strategies for the upgrade of methane conversion catalytic technologies.
\end{abstract}

Keywords: Cu-zeolites · Methane $\cdot$ Methanol $\cdot$ Partial oxidation $\cdot$ X-ray absorption spectroscopy

\section{Introduction - Methane Utilization and its Limitations}

While present efforts towards sustaining the situation of dwindling petroleum reserves are directed to harnessing renewable resources, not many solutions are at hand to bridge the transition between petroleum-based technologies to renewable energy-based systems. Methane or natural gas is an abundant, clean, and cheap resource that may support the fuel industry and supplement raw materials for chemical synthesis to bridge this transition. The World bank estimates that around 134 billion cubic meters of natural gas, instead of being used, is flared and vented annually worldwide. [1]

The problems associated with the direct use of methane to produce fuel and chemicals are strongly linked to its properties. Existing in the gas phase at ambient condi-

${ }^{*}$ Correspondence: Prof. Dr. J. A. van Bokhoven ETH Zurich

Institute for Chemical and Bioengineering

Wolfgang-Pauli-Strasse 10

$\mathrm{CH}-8093$ Zurich

Tel.: +41 446325542 (ETH)

Tel.: +4156 3105046 (PSI)

E-mail: jeroen.vanbokhoven@chem.ethz.ch tions, it is uneconomical to transport natural gas from remote drill sites. Converting methane to a functionalized liquid derivative such as methanol or heavier hydrocarbons would be a solution but the symmetric geometry of the methane molecule without a functional group gives no magnetic moment or polar distribution that facilitate chemical attack. ${ }^{[2]}$ Being a very weak base, its coordination to metal catalysts is a challenge. ${ }^{[3]}$ Its high $\mathrm{C}-\mathrm{H}$ bond strength (425 $\mathrm{kJ} / \mathrm{mol}$ ) requires forcing conditions such as temperature and pressure that often promote radical reactions in the gas phase. The use of strong oxidizing agents favors total oxidation since methane's partial oxidation products are more reactive than methane itself. As comparison, methanol has a C-H bond strength of $389 \mathrm{~kJ} / \mathrm{mol}$, is more basic and a better ligand than methane. It follows that acceptable selectivity is achieved at reaction conditions tuned to low methane conversion. Catalytic oxidation using heterogeneous catalysts reaches a limit of methanol selectivity of 30-40\% with methane conversion of 5-10\% under the best reaction conditions, such as temperatures of $450-500{ }^{\circ} \mathrm{C}$ and pressures of 30-60 bar. ${ }^{[4]}$ Therefore, the challenge to convert methane is related to selectivity rather than reactivity. ${ }^{[2]}$

Industrial processes of converting methane to liquid hydrocarbons, via the methanol-to-gasoline and Fischer-Tropsch routes start by the transformation of methane to synthesis gas (mixture of $\mathrm{H}_{2}$ and $\mathrm{CO})$ through steam reforming (Eqn. (1)). This step is highly endothermic, requiring high temperature $\left(>600{ }^{\circ} \mathrm{C}\right)$, hence, high energy consumption. An estimated $60 \%$ or more of the capital cost of a gas-to-liquid plant is associated with the reforming of methane to syngas. ${ }^{[2]}$

$$
\begin{aligned}
& \mathrm{CH}_{4}+\mathrm{H}_{2} \mathrm{O} \rightarrow \mathrm{Co}+3 \mathrm{H}_{2} \\
& \Delta \mathrm{H}_{298 \mathrm{~K}}=206 \mathrm{~kJ} / \mathrm{mol}
\end{aligned}
$$

\section{Proposed Alternative Catalytic Systems}

Two varieties exist for the partial oxidation of methane: a high-temperature route based on radical gas-phase reactions ${ }^{[5]}$ and a low-temperature route involving heterogeneous catalysis. High-temperature partial oxidation reactions $\left(350-500{ }^{\circ} \mathrm{C}\right)$ work under non-catalytic conditions, involving fuel-rich feed to minimize combustion, and inert reactor walls for good selectivity to methanol. In the presence of a catalyst, which is usually a redox oxide of the $\mathrm{MoO}_{3}$ and $\mathrm{V}_{2} \mathrm{O}_{5}$ type, the yield reaches a maximum value at high temperature $(650$ $\left.{ }^{\circ} \mathrm{C}\right)$ and low $\mathrm{O}_{2}$ partial pressure $\left(\mathrm{CH}_{4} / \mathrm{O}_{2}\right.$ $=1.8$ molar), with the maximum highest reported yield of $16 \%$ to $C_{1}$ oxygenates at atmospheric pressure. ${ }^{[6,7]}$ After methane activation by the surface oxygen species, the formed intermediate can be further attacked by reactive surface oxygen and is quickly oxidized into $\mathrm{HCHO}$ or $\mathrm{CO}_{\mathrm{x}}$. The protonation of methoxide to form methanol is very difficult if it is not protected from surface oxygen on neighboring sites, 
especially at high temperature where the dissociative adsorption of $\mathrm{O}_{2}$ on the catalyst surface is faster than the conversion of methane. ${ }^{[4]}$ The design of a catalyst that works at lower temperatures is vital for the direct synthesis of methanol. The structure of the active site should provide a Brønsted acid site for the protonation of methoxide and, at the same time, should protect the intermediate from further oxidation by surface oxygen on neighboring sites. ${ }^{4]}$

The demand for a defined active site and a reaction route that prevents oxidation of the intermediate has been achieved in homogeneous liquid phase oxidation systems and their heterogeneous counterparts that are based on well-defined single site systems. ${ }^{[3]}$ The low-temperature homogeneous activation of $\mathrm{C}-\mathrm{H}$ bonds leads to more selective reactions since they do not involve gas-phase radicals that propagate the reaction unselectively. The use of $\mathrm{K}_{2} \mathrm{PtCl}_{4}$ in the presence of stoichiometric amounts of $\mathrm{K}_{2} \mathrm{PtCl}_{6}$ at $<100{ }^{\circ} \mathrm{C}$ in acidic water converted methane to methanol and methyl chloride, without oxidizing methanol to $\mathrm{CO}{ }^{[8]}$ However, the stoichiometric Pt(IV) oxidant could not be regenerated by air. ${ }^{[9]}$ Subsequent oxidation catalysts based on $\mathrm{Pt}(\mathrm{II}), \mathrm{Pd}(\mathrm{II})$, and $\mathrm{Hg}$ (II) salts functionalized $\mathrm{C}-\mathrm{H}$ bonds and led to good yields of partially oxidized products. ${ }^{[10-12]}$ A (2,2'-bipyrimidine) $\mathrm{PtCl}_{2}$ catalyzed the selective oxidation of $\mathrm{CH}_{4}$ in fuming sulphuric acid to give methyl bisulphate in $72 \%$ one-pass yield at $81 \%$ selectivity based on methane (Eqn. (2)). The methane bisulfate intermediate is hydrolyzed to methanol (Eqn. (3)). The use of $\mathrm{H}_{2} \mathrm{SO}_{4}$ as solvent makes it difficult to separate $\mathrm{MeOH}$ from $\mathrm{H}_{2} \mathrm{SO}_{4}$, necessitating expensive corrosionresistant materials, and a periodic (costly) regeneration of spent sulfuric acid. To improve catalyst recovery, the active Pt complex has been successfully immobilized on a solid covalent triazine-based framework. ${ }^{[13]}$ The methanol concentration and turnover number of the supported Pt complex is similar to the homogeneous system while activity is maintained for several cycles. After the work by Periana and coworkers, organometallic approaches to methane conversion became an intense research area.[14-18]

Low-temperature partial oxidation of methane using a heterogeneous approach takes inspiration from the enzymatic systems. Cytochrome P450 is a large group of enzymes that catalyze the oxidation of organic compounds, the most common being a monooxygenase reaction: the insertion of an oxygen atom into an organic substrate while the other oxygen atom is reduced to water (Eqn. (4)). The active site contains a heme iron center that is crucial in the $\mathrm{C}-\mathrm{H}$ activation process. Methane monooxygenase (MMO) catalyzes the oxidation of methane to methanol (Eqn. (5)) at the physiological conditions of the host bacterium to provide for carbon and energy needs. MMO is (non-heme) structurally dissimilar to P450, and although both enzymes catalyze a range of similar reactions with the same overall stoichiometry, only MMO is capable of efficiently oxidizing methane. ${ }^{[19]}$

Two varieties of the MMO enzyme are known: the soluble (sMMO) type and the particulate (pMMO) type. The sMMO variant exists only in certain species of methanotrophs and under conditions of copper deficiency. Its active site contains a diiron center, which can change its exogenous ligand coordination and geometry that may be an important property for the catalytic cycle. ${ }^{[20]}$ Non-heme iron catalysts have been developed to mimic the alkane hydroxylation chemistry of sMMO, but they mostly resulted in complexes that generate alkoxyl or hydroxy radicals.[21] The $\alpha-O$ core in Fe-ZSM-5 that is formed upon reaction of the zeolite with $\mathrm{N}_{2} \mathrm{O},{ }^{[22-24]}$ capable of selectively oxidizing methane to methanol and benzene to phenol ${ }^{[25,26]}$ was suggested to mimic the active site in sMMO. ${ }^{[27,28]}$ The predominant form, pMMO, is found in all methanotrophs. Limitations in obtaining the pure enzyme that still retains its activity made pMMO difficult to study. On the basis of redox potentiometry and EPR spectroscopy on an active purified pMMO-enriched membrane, a ferromagentically coupled tricopper cluster has been proposed to be the active site for the enzyme, which may harness a singlet oxene, the most reactive form of the oxygen atom. ${ }^{[29-31]}$ Only two of the three reducing equivalents of copper are required for hydroxylation, while the third is required for efficient $\mathrm{O}$-atom transfer based on a concerted singlet oxene insertion across the $\mathrm{C}-\mathrm{H}$ bond. ${ }^{[32]}$ The $\mathrm{O}$-atom transfer only occurs when a substrate becomes bound in the proper stereochemical position to form the transition state allowing the oxo-transfer. ${ }^{[30]}$ More recent studies, showing the de-

$$
\begin{aligned}
& \mathrm{CH}_{4}+2 \mathrm{H}_{2} \mathrm{SO}_{4} \rightarrow \mathrm{CH}_{3} \mathrm{OSO}_{3}+\mathrm{SO}_{2}+2 \mathrm{H}_{2} \mathrm{O} \\
& \mathrm{CH}_{3} \mathrm{OSO}_{3}+\mathrm{H}_{2} \mathrm{O} \rightarrow \mathrm{CH}_{3} \mathrm{OH}+\mathrm{H}_{2} \mathrm{SO}_{4} \\
& \mathrm{RH}+\mathrm{O}_{2}+\mathrm{NADPH}+\mathrm{H}^{+} \rightarrow \mathrm{ROH}+\mathrm{H}_{2} \mathrm{O}+\mathrm{NADP}^{+} \\
& \mathrm{CH}_{4}+\mathrm{O}_{2}+\mathrm{NADPH}+\mathrm{H}^{+} \rightarrow \mathrm{CH}_{3} \mathrm{OH}+\mathrm{H}_{2} \mathrm{O}+\mathrm{NADP}^{+}
\end{aligned}
$$

pendence of pMMO activity on copper and complementary X-ray absorption spectroscopy (XAS) measurements indicate the active site in pMMO as a dicopper center, with the mixed-valent $\mathrm{Cu}(\mathrm{I} / \mathrm{II})$ atoms having a single set of $\mathrm{O} / \mathrm{N}$ ligands at $1.93 \AA$ and at a $\mathrm{Cu}-\mathrm{Cu}$ distance of $2.66 \AA$. ${ }^{[33,34]}$ The development of copper-containing zeolites that are active for the catalytic decomposition of nitrogen oxides ${ }^{[35-38]}$ and low-temperature partial oxidation of methane, ${ }^{[37-41]}$ indicated that they possess dicopper cores similar to pMMO, which has fuelled interest in copper-oxo chemistry and bio-inspired heterogeneous catalysts.

\section{Metal-Zeolite Systems for Methane to Methanol Conversion}

Zeolites are indispensable to heterogeneous catalytic reactions owing to their thermal stability, shape selectivity, and ability to maintain a high dispersion of metal sites in the microporous framework. The pentasil zeolites, such as ZSM-5 and mordenite (MOR), are reported to stabilize binuclear centers of $\mathrm{Fe}$ and $\mathrm{Cu}$, which are structurally analogous to those found in MMOs. Fe-ZSM-5, [28,42] Cu-ZSM-5, [39,43] and $\mathrm{Cu}-\mathrm{MOR}$ (Fig. 1) ${ }^{[39]}$ were reported to convert methane almost exclusively to methanol under mild conditions.

Fe-ZSM-5 converted methane to methanol at room temperature using $\mathrm{N}_{2} \mathrm{O}$ as an oxidant. ${ }^{[28]} \mathrm{Fe}^{3+}$ sites that are stabilized in the zeolite matrix undergo autoreduction to $\mathrm{Fe}^{2+}$ at high temperature to generate active sites capable of selective hydrocarbon oxidation. ${ }^{[4]}$ These active sites cannot be reoxidized by $\mathrm{O}_{2}$, but only by $\mathrm{N}_{2} \mathrm{O}$, to form the so-called $\mathrm{O}$-alpha sites, suggested to abstract hydrogen from methane to form hydroxy and methoxy groups on the alpha sites, followed by formation of methanol by hydrolysis of $\mathrm{Fe}-\mathrm{OCH}_{3}$ during extraction. ${ }^{[42]}$ Following the deposition of $\alpha$-oxygen $(100 \mu \mathrm{mol} / \mathrm{g} \mathrm{O} / \mathrm{g})$, the amount of methane which reacted was determined to be $\mathrm{CH}_{4}: \mathrm{O}_{\alpha}=1: 1.75$ based on pressure drop measurements. Extraction identified dimethyl ether comprising $\sim 5 \%$ of the amount of reacted methane regardless of the nature of the solvent. Addition of water enhanced methanol extraction leading to an ultimate total yield of $75 \%$ of the methane oxidation products (methanol + DME) to be recovered by (offline) extraction. The missing amount remained on the catalyst surface and was recovered in the form of $\mathrm{CO}_{\mathrm{x}}$ by heating. ${ }^{[42]}$ Recently, Fe-ZSM-5 was found to activate hydrogen peroxide in an aqueous environment to serve as both oxidant and reagent for the hydrolysis of intermediates, and thus converted methane to methanol at selectivities above $85 \%$ and activities ( $>2200$ TOF) at three orders of 


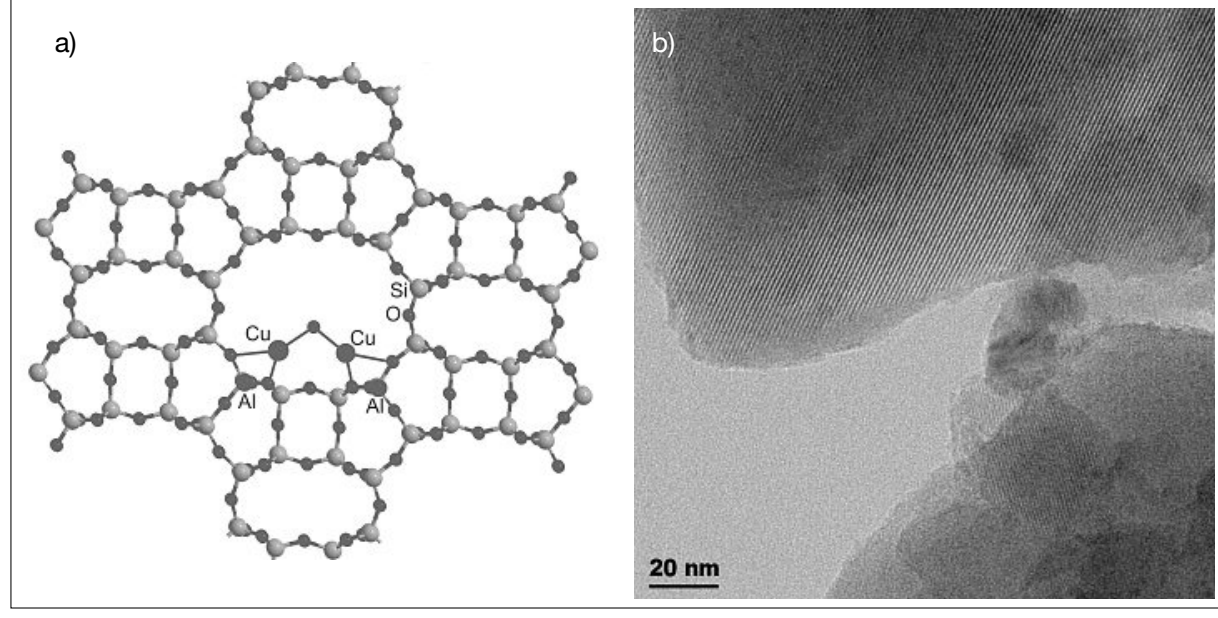

Fig. 1. (a) Mordenite zeolite framework with a schematic representation of impregnated Cu at the main channel and (b) TEM picture of synthesized Cu-MOR showing uniform zeolite channels with no observable metal particles.

magnitude higher than previous reports. ${ }^{[45]}$ The addition of $\mathrm{Cu}^{2+}$, either as a component of the heterogeneous catalyst or as additive to the reaction mixture, reduced the over-oxidation process.

$\mathrm{Cu}$-zeolites were first reported to convert methane to methanol starting at $130{ }^{\circ} \mathrm{C}$ by cleaving molecular $\mathrm{O}_{2} \cdot{ }^{[39,46]}$ Detection of the formed methanol required extraction or indirect observation as $\mathrm{CO}_{2}$ by heating the catalyst bed. On the basis of UV-Vis measurements, the active site was first characterized as a bis( $\mu$-oxo) dicopper center, proposed to be the same active site catalyzing the decomposition of nitric oxide. ${ }^{[37]}$ Subsequent complementary resonant Raman characterization on $\mathrm{Cu}-\mathrm{ZSM}-5$ revised the structure of the active center to a bent mono( $\mu$-oxo)dicopper center. ${ }^{[40,47]}$ Correlating the intensities of the FT-IR bands associated with adsorbed pivalonitrile and NO on copper species with the methanol yield allowed a parallel study to show that $\mathrm{Cu}-\mathrm{O}$ clusters dispersed outside the ZSM-5 surface were not involved in the oxidation reaction while the $\mathrm{Cu}-\mathrm{O}$ species inside the zeolite channels were responsible for converting methane to methanol.[43]

With Co-ZSM-5, the partial oxidation of methane to oxygenates at $150{ }^{\circ} \mathrm{C}$ was carried out using air as oxidant. ${ }^{[48]}$ The Co species in ion-exchange positions were selective towards formaldehyde, while the oxidic Co species, in the form of $\mathrm{CoO}$ and $\mathrm{Co}_{3} \mathrm{O}_{4}$, were active for the production of methanol.

For these systems, the methane to methanol conversion process required three successive steps: 1 ) activation, where high-temperature treatment is essential for the formation of the active metal-oxygen precursors, 2) reaction with methane, the selective reaction of the oxygenated metal sites with methane to form a partially oxidized sorbed product, and 3) desorption, the need to extract the product, which is the only means to directly observe methanol. The need for desorption of the product is one of the main challenges in these systems since a catalytic process could not be established. In addition, the reported small amount of active metal centers compared to the total amount of metal, makes the elucidation of the structure of the active site a challenge and hinders the understanding of the reaction mechanism, which is necessary for further developments.

\section{Methane to Methanol over Cu-zeolite}

\subsection{Synthesis}

Based on the encouraging findings described above, we aimed to produce a complete route from methane to methanol without the need for ex situ extraction, and to decipher the structure of the active site and intermediates to gain insights into the reaction mechanism. We chose $\mathrm{Cu}$ since it was shown to activate molecular $\mathrm{O}_{2}$, which could later be possibly taken from air, and because $\mathrm{pMMO}$ has been reported to contain $\mathrm{Cu}$ as its active site. The MOR topology was chosen since a higher amount of extracted methanol was reportedly obtained from $\mathrm{Cu}-\mathrm{MOR}$ than $\mathrm{Cu}-\mathrm{ZSM}-5$, suggesting that two different active sites may be present in $\mathrm{Cu}-\mathrm{MOR}$, one reacting at higher temperatures. ${ }^{[39,46]}$

The presence of $\mathrm{Al}^{3+}$ ions in the zeolite framework, substituting $\mathrm{Si}^{4+}$, imparts a negative charge that is balanced by either protons or transition metal ions (TMI). The TMIs are introduced into the framework through aqueous or solid-state ion exchange with the existing counterion (usually $\mathrm{H}^{+}$or $\mathrm{Na}^{+}$). Aqueous ion exchange (AIE) with $\mathrm{Cu}$ is performed under conditions where the cation is present as a hexaaquo-complex of $\mathrm{Cu}^{2+}{ }^{2}{ }^{[49]} \mathrm{A}$ solu- tion of copper acetate in water at a $\mathrm{Cu}^{2+}$ concentration of $0.01 \mathrm{M}$ is kept below $\mathrm{pH}$ $=6$ to avoid polymerization to $\mathrm{Cu}(\mathrm{OH})_{2}{ }^{[50]}$ The introduction of the maximum amount of $\mathrm{Cu}^{2+}$ content at the ion exchange positions is often sought since adsorptive and catalytic activity usually increases with increasing $\mathrm{Cu} / \mathrm{Al} .^{[51]}$ Considering electrostatics, the $\mathrm{Cu}$ ions are expected to preferentially occupy sites close to framework aluminum ions. However, the exact position of the aluminum ions in the lattice is not known, especially for zeolites with high $\mathrm{Si} / \mathrm{Al}$ ratios such as MOR and ZSM-5. There is a consensus about $\mathrm{Cu}$ assuming an octahedral coordination to $\mathrm{H}_{2} \mathrm{O}, \mathrm{OH}$ and $\mathrm{O}$ ligands after ion exchange. Our $\mathrm{Cu}-\mathrm{MOR}$ material was synthesized by aqueous ion exchange at room temperature of copper acetate with Na-MOR as previously reported. ${ }^{[39,52]}$

\subsection{Formation of the Active Site}

Calcination or thermal treatment of the AIE-prepared material in oxygen is essential to eliminate organic matter associated with the AIE and to form the active site. After dehydration in inert gas, the $\mathrm{Cu}$ ions undergo autoreduction. Heating in oxygen atmosphere ensures that copper is kept in a $\mathrm{Cu}^{2+}$ state. The unsaturated metal coordination environment allows the metal centers to coordinate adsorbed molecules and act as catalytically active sites. The identity of the $\mathrm{Cu}$ centers dictates their catalytic performance and depending on synthesis and pretreatment conditions, varying amounts of isolated $\mathrm{Cu}^{2+}$ species, $\mathrm{CuO}$ and $(\mathrm{Cu}-\mathrm{O}-\mathrm{Cu})^{2+}$ may be present. There is disagreement in the literature on the nature of the $\mathrm{Cu}$ species, their amounts, and the mechanisms involved to arrive at such distributions. Cu-ZSM-5 is the most studied system by virtue of its activity for NO decomposition; hence it will be the focus of the following discussion.

The first suggested mechanism for the formation of the active site during thermal treatment is the condensation of neighboring $\left[\mathrm{Cu}^{2+} \mathrm{OH}\right]^{-}$species to form $\left[\mathrm{Cu}^{2+} \mathrm{O}^{2-}\right.$ $\mathrm{Cu}^{2+}$ groups while water is eliminated (Eqn. (6)). A consecutive step reduces both $\mathrm{Cu}^{2+}$ ions to form $\left[\mathrm{Cu}^{+}-\square-\mathrm{Cu}^{+}\right]$, where $\square$ is a vacancy of extralattice oxygen introduced to the framework during the ion exchange process.

The second proposed mechanism is a disproportionation process ${ }^{[53]}$ to form isolated $\mathrm{Cu}$ sites (Eqn. (7)). It is based on the assumption that the release of a hydroxyl radical $\left(\bullet \mathrm{OH}^{-}\right)$is involved. All copper ions in hydrated $\mathrm{Cu}-\mathrm{ZSM}-5$ are detected by EPR while only $\sim 40-60$ are detected in a dehydrated sample. Supposing that the undetected fraction was reduced $\mathrm{Cu}^{+}$and from the observation that the $\mathrm{Cu}^{2+} \mathrm{EPR}$ intensity can be recovered after exposure 


$$
2[\mathrm{CuOH}]^{+} \rightarrow \mathrm{H}_{2} \mathrm{O}+\left[\mathrm{CU}^{2+}-\mathrm{O}^{2-}-\mathrm{Cu}^{2+}\right]^{2+} \rightarrow\left[\mathrm{Cu}^{+}-\square-\mathrm{Cu}^{+}\right]+1 / 2 \mathrm{O}_{2}
$$

$$
2[\mathrm{CuOH}]^{+} \rightarrow \mathrm{H}_{2} \mathrm{O}+\mathrm{Cu}^{+}+\mathrm{Cu}^{2+} \mathrm{O}^{-}
$$

of a thermally treated Cu-ZSM-5 with water led to the following proposed mechanism.

The $[\mathrm{CuOH}]^{+}$species reduces to $\mathrm{Cu}^{+}$ accompanied by the release of a hydroxyl radical, which then subsequently reacts with another $[\mathrm{CuOH}]^{+}$moiety to produce $\mathrm{Cu}^{2+} \mathrm{O}^{-}$and water. Since $\mathrm{O}^{-}$and $\mathrm{Cu}^{2+}$ are paramagnetic, the resulting $\mathrm{Cu}^{2+} \mathrm{O}^{-}$will not be observed by EPR. According to this mechanism, it is unclear why only a part of the copper is autoreduced. Differences in the nature of the sites occupied by $[\mathrm{CuOH}]^{+}$, whether near isolated $\mathrm{Al}$ or near $\mathrm{Al}-\mathrm{Al}$ exchange centers, was cited as a reason. ${ }^{[53]}$ When the pretreated sample was exposed to oxygen, no increase was observed in the EPR signal although a distinct color change from purple to yellow green was observed, indicating a change in oxidation state. This was interpreted as the oxidation of $\mathrm{Cu}^{+}$to $\mathrm{Cu}^{2+} \mathrm{O}_{2}^{-}$, where both species are EPR silent. The formation of copper pairs $[\mathrm{CuOCu}]^{2+}$ was excluded because of the absence of a half-field EPR signal, similar to that observed for copper pairs in $\mathrm{CuY}$. ${ }^{[54]}$

Magnetic susceptibility and optical diffuse reflectance spectroscopy, complementing EPR, led Lo Jacono and coworkers ${ }^{[55]}$ to show that the change in EPR signal intensity between hydrated and dehydrated Cu-ZSM-5 was caused by a decrease in symmetry accompanying dehydration rather than by disproportionation of $[\mathrm{CuOH}]^{+}$into $\mathrm{Cu}^{+}$and $\mathrm{Cu}^{2+} \mathrm{O}^{-}$as water is removed. They refuted the significant contribution of the EPR silent conventional bridge species $\mathrm{Cu}^{2+} \mathrm{O}^{2-} \mathrm{Cu}^{2+}$ since the small antiferromagnetic coupling cannot be responsible for the large intensity changes observed for EPR spin intensity on dehydration. The bridge $\mathrm{Cu}^{2+} \mathrm{O}^{2-} \mathrm{Cu}^{2+}$ species, if it is present, appears only in limited amounts, involving only about $20 \%$ of the total $\mathrm{Cu}$. A strong emphasis was made regarding high-temperature oxidation: that the intensity of the $\mathrm{Cu}^{2+} \mathrm{EPR}$ signal following pretreatment and calcination in oxygen does not represent a measure of the total amount of copper in the zeolite. ${ }^{[53]}$

Reduction of the $\mathrm{Cu}^{2+}$ species in ZSM5 that were introduced by AIE allowed Wichterlova and co-workers [56,57] to use photoluminescence spectroscopy and probe the resulting $\mathrm{Cu}^{+}$sites. The appearance of distinct emission bands at $540 \mathrm{~nm}$ and $480 \mathrm{~nm}$ after reducing Cu-ZSM-5 in hydrogen at $350{ }^{\circ} \mathrm{C}$ allowed them to assign different $\mathrm{Cu}$ sites with different reducibility: one $(540 \mathrm{~nm})$ in the vicinity of an isolated $\mathrm{Al}$ and the other $(480 \mathrm{~nm})$ near an $\mathrm{Al}-\mathrm{Al}$ pair, respectively. The exchange centers near $\mathrm{Al}-\mathrm{Al}$ pairs are preferentially occupied, while the ones near isolated $\mathrm{Al}$ atoms are occupied at increasing $\mathrm{Cu}$ loadings as monovalent complexes. Lamberti and co-workers, ${ }^{[58]}$ using combined XAS, IR and UV-Vis measurements on a $\mathrm{Cu}^{+}$ ZSM-5 material synthesized through gasphase exchange of $\mathrm{CuCl}$, also identified two different $\mathrm{Cu}^{+}$sites and proposed that the difference between the two exchange sites may be due to the first coordination shell of the anchored copper. The first family of $\mathrm{Cu}^{+}$sites is surrounded by three equivalent nearest neighbor framework oxygens at about $2 \AA$, all exposed in the channel. The second family refers to $\mathrm{Cu}^{+}$ions surrounded by only two equivalent nearest neighbor framework oxygens at about $2 \AA$, and by a third more internally located oxygen atom at about $3 \AA$. These assignments are supported by analysis of the extended X-ray absorption fine structure (EXAFS) spectra showing $2.5 \pm 0.3$ oxygens at $2 \AA$. XAS allowed Kumashiro and co-workers $^{[59]}$ to monitor the $\mathrm{Cu}$ sites during evacuation of $\mathrm{Cu}$-ZSM5 from RT to $600{ }^{\circ} \mathrm{C}$ to complement the luminescence data. They observed that the emission bands centered at $480 \mathrm{~nm}$ (near $\mathrm{Al}-\mathrm{Al}$ pair) and 540 $\mathrm{nm}$ (near isolated $\mathrm{Al}$ ) appeared at $300{ }^{\circ} \mathrm{C}$ and increased in intensity with increasing evacuation temperature. The $8.983 \mathrm{keV}$ feature in the $\mathrm{Cu} \mathrm{K}$-edge XANES, associated with the $1 \mathrm{~s} \rightarrow 4 \mathrm{p}$ transition, was also developed at $300{ }^{\circ} \mathrm{C}$, confirming the presence of $\mathrm{Cu}^{+}$species. Using the spectrum of $\mathrm{Cu}-\mathrm{ZSM}-5$ evacuated at room temperature and that of $\left[\mathrm{Cu}\left(\mathrm{NH}_{3}\right)_{2}\right]^{+}$as references for divalent and monovalent $\mathrm{Cu}$, respectively, $70 \%$ of the total $\mathrm{Cu}$ ions was estimated to reduce to $\mathrm{Cu}^{+}$by evacuation until $600{ }^{\circ} \mathrm{C}$. The authors assumed that the reduction mechanism is similar between Cu-ZSM-5 and $\mathrm{Cu}-\mathrm{MOR}$, both being high-silica type zeolites. $\mathrm{CO}$ adsorption measurements showed three adsorption ranges in the chemisorption region, suggesting the presence of at least three kinds of $\mathrm{Cu}^{+}$species in the ratio $2: 3: 1$. The IR bands associated with the $\mathrm{Cu}^{+}-\mathrm{CO}$ complexes suggested that the two $\mathrm{Cu}^{+}$species are located in the ion-exchange sites while the other $\mathrm{Cu}^{+}$species is located on a silica-like surface.

Extension of the multi-spectroscopic technique system to ion-exchanged $\mathrm{Cu}$ ZSM-5 during thermal treatments ${ }^{[60]}$ showed a two-step reduction process. Thermal treatment below $200{ }^{\circ} \mathrm{C}$ brings about the loss of water without reduction of the $\mathrm{Cu}^{2+}$ ions as seen from the X-ray absorption near edge (XANES) region of the XAS spectra. The dehydration causes rearrangement of the cupric species inside the channels of the zeolites, in which a fraction becomes EPR silent. Reduction of the cupric ions to $\mathrm{Cu}^{+}$, with oxygen elimination occurs beyond $200{ }^{\circ} \mathrm{C}$. Oxidation by molecular oxygen in a dehydrated environment does not occur at room temperature, but is facilitated by water. The presence of $\mathrm{Cu}-\mathrm{Cu}$ dimers was suggested from the analysis of the EXAFS spectra. On $\mathrm{Cu}-\mathrm{MOR}^{[61]}$ the same effects as for $\mathrm{Cu}-\mathrm{ZSM}-5$ up to $200{ }^{\circ} \mathrm{C}$ was observed. Unlike $\mathrm{Cu}$-ZSM-5 however, the reduction process for $\mathrm{Cu}-\mathrm{MOR}$ was not completed at $400{ }^{\circ} \mathrm{C}$ where $30 \%$ of the cupric ions was still present. The presence of (EPR inactive) $\mathrm{Cu}^{2+} \mathrm{O}^{2-} \mathrm{Cu}^{2+}$ complexes, identified by EXAFS analysis, was proposed to be the cause for systematic underestimation of the fraction of $\mathrm{Cu}^{2+}$ species estimated by EPR compared to that by XANES.

The importance of these EPR silent species was emphasized when the reactive $\mathrm{Cu}^{2+}$ core was associated with EPR silent $\mathrm{Cu}$ species. Increasing the $\mathrm{Cu}$ loading, leading to overexchange, increases the amount of EPR silent species. ${ }^{[62]}$ As soon as the $\mathrm{Cu} / \mathrm{Al}$ ratio was greater than 0.20 $(\mathrm{Cu}-\mathrm{ZSM}-5, \mathrm{Si} / \mathrm{Al}=12, \mathrm{EPR}$-silent $\mathrm{Cu}=$ $0.5 \mathrm{wt} \%), \mathrm{Cu}-\mathrm{ZSM}-5$ shows a burst of catalytic activity for $\mathrm{N}_{2} \mathrm{O}$ decomposition. ${ }^{[63]}$ The catalytic activity of $\mathrm{Cu}-\mathrm{ZSM}-5$ was also correlated to the manifestation of a UV-Vis charge transfer (CT) absorption band at $22700 \mathrm{~cm}^{-1}$. The intensity of the CT band increased with increasing $\mathrm{Cu}$ / $\mathrm{Al}$ value. The $\mathrm{Cu} \mathrm{K}$-edge XANES spectra measured of the $\mathrm{O}_{2}$ activated Cu-ZSM-5 showed a $1 \mathrm{~s} \rightarrow 3 \mathrm{~d}$ feature at $8977.5 \mathrm{eV}$, that is characteristic of $\mathrm{Cu}^{2+}$ state, and a $1 \mathrm{~s} \rightarrow 4 \mathrm{p}$ feature at $8987 \mathrm{eV}$ that resembles the features of a $\mathrm{Cu}(\mathrm{OH})_{2}$ spectrum, suggesting a manifestation of planar symmetry. ${ }^{[37]}$ The difference in the resonance features above the edge jump suggested an ordering around the $\mathrm{Cu}^{2+}$ ions of $\mathrm{Cu}$ ZSM-5 deviated from the parallel chains of $\mathrm{Cu}(\mathrm{OH})_{2}$. The fit of the EXAFS spectra showed a Cu-O contribution at $1.95 \AA$ with a coordination number $(\mathrm{N})$ of 4 . $\mathrm{A} \mathrm{Cu}-\mathrm{Cu}$ contribution at $2.87 \AA$ was found with $\mathrm{N}$ $=0.9$, suggesting the presence of dimeric, mixed monomeric, or oligomeric copper species. ${ }^{[38]}$ This strongly matched with the $\mathrm{Cu}-\mathrm{Cu}$ separation of 2.79-2.92 $\AA$ reported for the bis( $\mu$-oxo)dicopper species. The bis( $\mu$-oxo)dicopper species is EPR silent and exhibits a pair of CT bands at around $22300-25000$ and $30800-32700 \mathrm{~cm}^{-1}$, in agreement with the CT band of activated $\mathrm{Cu}-Z \mathrm{ZSM}-5$ at $22700 \mathrm{~cm}^{-1}$ and $30000 \mathrm{~cm}^{-1}$. These strong spectroscopic similarities prompted the assignment of a bis( $\mu$-oxo) dicopper species in $\mathrm{Cu}-\mathrm{ZSM}-5$ despite the $\mathrm{Cu}^{3+}$ formal oxidation state of the dicopper core. The same $\mathrm{Cu}$ species was identified 
active for selectively converting methane to methanol. ${ }^{[39]}$ Probing the same system with resonant Raman (rR) spectroscopy ${ }^{[40]}$ showed isotope-sensitive fundamental vibrations at $237 \mathrm{~cm}^{-1}, 456 \mathrm{~cm}^{-1}$, and 870 $\mathrm{cm}^{-1}$ and an overtone band at $1725 \mathrm{~cm}^{-1}$, which were found to correspond instead to the vibrations of an EPR silent bent mono( $\mu$-oxo)dicopper species, though DFT calculations showed that this species will exhibit a CT band at $23400 \mathrm{~cm}^{-1}$ corresponding to the $\mathrm{Cu}^{2+} \rightarrow \mathrm{O}$ transition. DFT coupled to normal coordinate analysis resulted in a fitted structure of a $<\mathrm{Cu}-\mathrm{O}-\mathrm{Cu}$ angle of $139^{\circ}, \mathrm{a} \mathrm{Cu}-\mathrm{Cu}$ distance of 3.29 $\AA$, and $\mathrm{Cu}-\mathrm{O}$ bond lengths of $1.74-1.75$ $\AA .{ }^{[40]}$ The absence of a symmetric stretch vibration at around $600 \mathrm{~cm}^{-1}$ excluded the bis( $\mu$-oxo $)$ dicopper species.

\subsection{High-resolution XAS and EXAFS of $\mathrm{Cu}-\mathrm{MOR}$}

Based on these reports, we used XAS at the $\mathrm{Cu}$ K-edge $(\sim 9 \mathrm{keV})$ to monitor the spectroscopic fingerprints of $\mathrm{Cu}$ atoms in $\mathrm{Cu}-\mathrm{MOR}$ under different gas feeds. ${ }^{[52,64]}$ The multiplicity of the final states $(3 \mathrm{~d}, 4 \mathrm{p}$ or $4 \mathrm{~s}$ ) complicates the interpretation of the features in the XANES region such that an especially good spectral resolution is needed. The XANES features are broadened because of the finite lifetime of the core hole. ${ }^{[65]}$ The use of high energy resolved fluorescence detected (HERFD) XAS ${ }^{[66]}$ allows a better resolution of features in the XANES region due to the use of a single fluorescence line at an energy resolution better than that of the core hole lifetime broadening. The HERFD spectra have better resolved fine structure compared to the XANES spectra measured in transmission mode by eliminating the broadening attributed to the core hole. Coupling the electronic information obtained from HERFD XAS and the geometric information from the EXAFS spectroscopy allowed us to follow the structure of the $\mathrm{Cu}$ sites under the different gas feeds. The in situ XAS measurements at the $\mathrm{Cu}$ K-edge were performed at the SuperXAS beamline of the Swiss Light Source in Villigen, Switzerland. The HERFD XAS spectra were collected in fluorescence mode using a Johann-type spectrometer with a spherically bent $\mathrm{Si}(444)$ crystal, ${ }^{67]}$ while the EXAFS measurements were made in conventional transmission geometry.

Calcination in oxygen was performed in situ before every reaction. We have reproduced the reported presence of a UVVis band assigned to the active $\mathrm{Cu}$ core at $22700 \mathrm{~cm}^{-1}$ after calcination at $450{ }^{\circ} \mathrm{C}$ in oxygen and the disappearance of this UVVis feature after reaction with methane at $200{ }^{\circ} \mathrm{C}$. During heating in oxygen for the activation of $\mathrm{Cu}$ sites (Fig. 2), the pre-edge at $8976.5 \mathrm{eV}$ gained intensity with increase in the temperature up to $250{ }^{\circ} \mathrm{C}$ and the rising edge feature shifted from $8988 \mathrm{eV}$ to a more prominent feature at $8986 \mathrm{eV}$. The constant position of the pre-edge and the localization of the rising edge above $8984 \mathrm{eV}$ is indicative of a constant $\mathrm{Cu}^{2+}$ state. The shift in the rising edge may be attributed to small changes in covalency or coordination of the $\mathrm{Cu}$ sites such as the loss of ligated water that is a significant process known to occur during thermal treatment. ${ }^{[68]}$ An observed decrease in the intensity of the feature at maximum absorption at $8995 \mathrm{eV}$ may also be attributed to the change in oxygen coordination by water loss although multiple excitation effects cannot be excluded. ${ }^{[69]}$ The Fouriertransformed EXAFS spectra of $\mathrm{Cu}-\mathrm{MOR}$ show a coordination shell around $1.6 \AA$ (not phase corrected), which was fitted with 4 to 5 oxygen backscatterers at $1.89-1.93 \AA$ A. A second coordination shell was barely observable and difficult to fit unambiguously.

\subsection{How many Cu Sites Participate during Reaction with Methane and Extraction?}

The reaction of methane to methanol over an active $\mathrm{Cu}$ core to methane was first probed by UV-Vis. ${ }^{[39]}$ The reaction of an oxygen-activated $\mathrm{Cu}-\mathrm{ZSM}-5(\mathrm{Si} / \mathrm{Al}=12$, $\mathrm{Cu} / \mathrm{Al}=0.58)$ with methane caused the 22 $700 \mathrm{~cm}^{-1} \mathrm{CT}$ band to decrease in intensity with time. The decay showed a first order reaction with activation energy of $15.7 \pm 0.5$ $\mathrm{kcal} / \mathrm{mol}$. The reaction had a kinetic isotope effect $\left(3.1 \pm 0.5 \mathrm{kcal} / \mathrm{mol}\right.$ at $\left.175{ }^{\circ} \mathrm{C}\right)$ from an Arrhenius plot of the reaction with ${ }^{13} \mathrm{CH}_{4}$ indicating that $\mathrm{C}-\mathrm{H}$ bond breaking is the rate-limiting step. DFT calculations showed that the formation of a $[\mathrm{Cu}-\mathrm{OH}-$ $\mathrm{Cu}]^{2+}$ intermediate upon reaction of methane with the dicopper species agrees with the energy barrier $(18.5 \mathrm{kcal} / \mathrm{mol})$ obtained from experimental data $(15.7 \mathrm{kcal} / \mathrm{mol})$. The $[\mathrm{Cu}-\mathrm{OH}-\mathrm{Cu}]^{2+}$ intermediate was best described as a delocalized radical species, where the stronger $\mathrm{O}-\mathrm{H}$ bond of this intermediate relative to the $\mathrm{H}-\mathrm{CH}_{3}$ bond helps to drive $\mathrm{H}$ atom abstraction. ${ }^{[40]} \mathrm{On}$ the premise of a reactive mono( $\mu$-oxo)dicopper core, one of the low lying singly occupied molecular orbitals of the $\mathrm{Cu}-\mathrm{O}-\mathrm{Cu}$ species gains significant oxygen $\mathrm{p}$-character oriented into the zeolite channel and towards the $\mathrm{H}-\mathrm{CH}_{3}$ bond of methane resulting in the formation of a cupric-oxyl $\left(\mathrm{Cu}^{2+} \mathrm{O}^{-}\right.$$\mathrm{Cu}^{+}$) radical intermediate. This cupric-oxyl species has been considered highly active for $\mathrm{H}$ atom abstraction, although it has not yet been observed experimentally. ${ }^{[40]}$ The overall reaction (Eqn. (8)) was described to proceed by the rebound of the hydroxyl radical to couple with the methyl radical to complete the methane to methanol reaction. For $\mathrm{Cu}-\mathrm{MOR}$, the $22200 \mathrm{~cm}^{-1}$ band that was attributed to the $\mathrm{Cu}$ core also diminished in intensity after reaction with methane at $200{ }^{\circ} \mathrm{C}$. ${ }^{[39,46]}$

The amount of active $\mathrm{Cu}$ species that reacts with methane was estimated from the amount of methanol that was detected from GC analysis after extraction with 1:1 water/acetonitrile mixture at room temperature. The extracted amount for Cu-ZSM-5 was typically $8.15 \mu \mathrm{mol} \mathrm{g}{ }^{-1} \mathrm{MeOH}$. Based on an assumed $\mathrm{Cu}: \mathrm{MeOH}$ stoichiometry of $2: 1$, approximately $4.6 \%$ of the $\mathrm{Cu}$ atoms were proposed to participate in the selective conversion of methane to methanol. They showed that above $\mathrm{Cu} / \mathrm{Al}=0.3$ the methanol yield reaches a plateau while the intensity of the $22700 \mathrm{~cm}^{-1}$ band still increases. Temperature programmed desorption results showed that only $38 \%$ of the methanol was extracted from the highly-loaded $\mathrm{Cu}-\mathrm{ZSM}-5$ samples, and so difficulty arises in interpreting whether a similar fraction of unextractable methanol can be expected for other zeolite topologies. ${ }^{[46]} \mathrm{A}$ higher amount of $\mathrm{MeOH}$ was extracted for $\mathrm{Cu}-\mathrm{MOR}\left(11.3 \mu \mathrm{mol} \mathrm{g}^{-1}\right.$ $\mathrm{MeOH})$. The 12-ring pores in MOR were suggested to facilitate the extraction compared to the 10-ring pores in ZSM-5. The methanol yield increased even further (13 $\left.\mu \mathrm{mol} \mathrm{g} \mathrm{g}^{-1} \mathrm{MeOH}\right)$ when the methane reaction temperature was increased to $200{ }^{\circ} \mathrm{C}$ for $\mathrm{Cu}-\mathrm{MOR}$, suggesting that a second reactive species is present in $\mathrm{Cu}-\mathrm{MOR}$ that contributes only at higher temperature, requiring further investigation. ${ }^{[46]}$ The $r R$ measurements ${ }^{[40]}$ showed that the Raman vibrations associated with the $\mathrm{Cu}-\mathrm{O}-\mathrm{Cu}$ active site for methanol synthesis are lost after reaction with methane at $200{ }^{\circ} \mathrm{C}$,

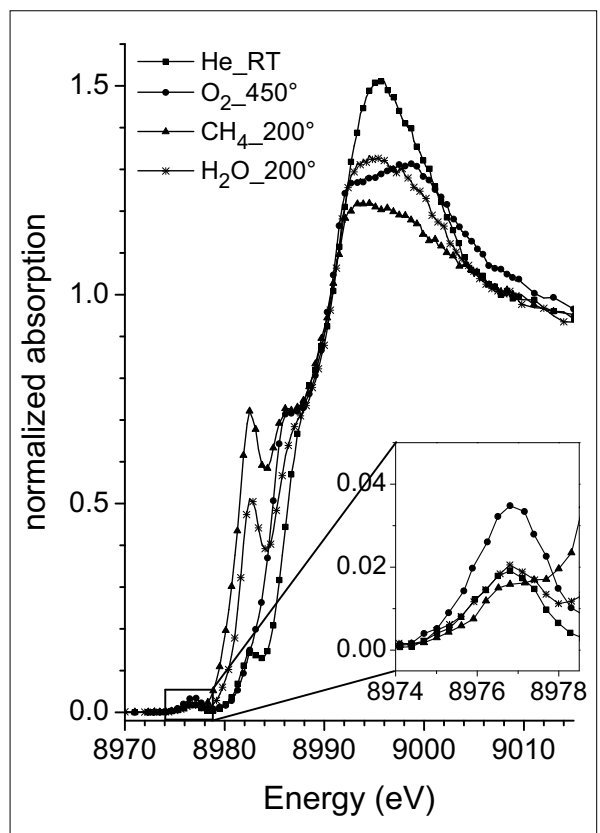

Fig. 2. HERFD XANES spectra of Cu-MOR taken of the starting material, during calcination in $\mathrm{O}_{2}$, methane reaction, and water-assisted desorption. 


$$
[\mathrm{Cu}-\mathrm{O}-\mathrm{Cu}]^{2+}+\mathrm{CH}_{4} \rightarrow\left[\mathrm{Cu}-{ }^{-} \mathrm{OH}-\mathrm{CU}\right]^{2+}+{ }^{\circ} \mathrm{CH}_{3} \rightarrow 2 \mathrm{Cu}^{+}+\mathrm{CH}_{3} \mathrm{OH}
$$

similar to the observations made by UVVis measurements, suggesting the loss of $\mathrm{Cu}-\mathrm{O}-\mathrm{Cu}$ structure after the reaction with methane and confirming that the rR vibrations are from the active site.

By taking out our $\mathrm{Cu}-\mathrm{MOR}$ material after interaction with methane and by stirring it in water at room temperature with subsequent gas chromatographic analysis, the amount of methanol that was extracted was $13 \mu \mathrm{mol} \mathrm{MeOH/g} \mathrm{Cu-MOR,} \mathrm{compa-}$ rable to the previously reported value using a 1:1 water/acetonitrile extraction medium. ${ }^{[39]}$ To indirectly observe the methane activation product, we heated the catalyst bed in inert gas and observed $\mathrm{CO}_{2}$ by mass spectrometry, in agreement with the earlier studies. The available oxygen in the lattice may be responsible for the oxidation of the adsorbed intermediate to $\mathrm{CO}_{\mathrm{x}}$ at high temperature. ${ }^{[4]}$ During the reaction with methane (Fig. 2), the appearance of an $8983 \mathrm{eV}$ feature in our HERFD XANES spectra suggested either the formation of a linearly coordinated $\mathrm{Cu}(\mathrm{I})$ complex or a manifestation of mixed $\mathrm{Cu}(\mathrm{II}) / \mathrm{Cu}(\mathrm{I})$ states. ${ }^{[64]}$ A linear combination fit procedure was performed (Fig. 3) using the spectra of $\mathrm{Cu}$ MOR taken during stepwise reduction in hydrogen as references for $\mathrm{Cu}^{2+}, \mathrm{Cu}^{+}$and $\mathrm{Cu}^{0}$. The fit showed the presence of $37 \%$ $\mathrm{Cu}(\mathrm{II})$ and $63 \% \mathrm{Cu}(\mathrm{I})$ in the total $\mathrm{Cu}$ content. [64]

If after methane interaction, without changing temperature, a wet stream of helium was allowed to flow through the catalyst material, methanol was observed in the gas phase as shown by the $m / z=31$ signal of the mass spectrometer. Methanol was detected only during the introduction of the wet helium stream, when the effluent was channeled to a cold trap and subsequently analyzed by GC. Subsequent heating in helium after desorbing methanol did not show $\mathrm{CO}_{2}$, which indicated that the intermediate of methane conversion was removed and enabled us to only detect gas phase methanol. We proposed that the role of steam is the reaction of the intermediate to methanol or the displacement of methanol by competitive adsorption. We have shown that the system can be operated in a batch-wise manner, allowing multiple turnovers and opening the possibility of operating the system in a catalytic cycle. ${ }^{[52]}$ Most of the spectral features observed during methane interaction remained similar after interaction with a wet helium stream, which suggests that a large fraction of the intermediates that are formed do not desorb. The EXAFS spectra manifests an almost stable $\mathrm{Cu}-\mathrm{O}$ first shell configuration during all stages in the reaction, which indicates that the changes to the $\mathrm{Cu}$ sites are dominated by redox processes without major structural rearrangements. Our observation of a $\mathrm{Cu}$ (II) state for the oxygenactivated $\mathrm{Cu}-\mathrm{MOR}$ using XAS and the absence of any evidence of a $\mathrm{Cu}$ (III) signature corroborates with a dicopper (II) species proposed from the $\mathrm{rR}$ measurements. However, our findings based on XAS show that a large fraction of $\mathrm{Cu}$ changes structure during reaction ( $>60 \%$ in $\mathrm{Cu}-\mathrm{MOR}$ ). This opposes the initially suggested minority ( $\sim 5 \%$ in $\mathrm{Cu}-\mathrm{ZSM}-5)$ of active copper sites, which was estimated from the amount of methanol that could be extracted.

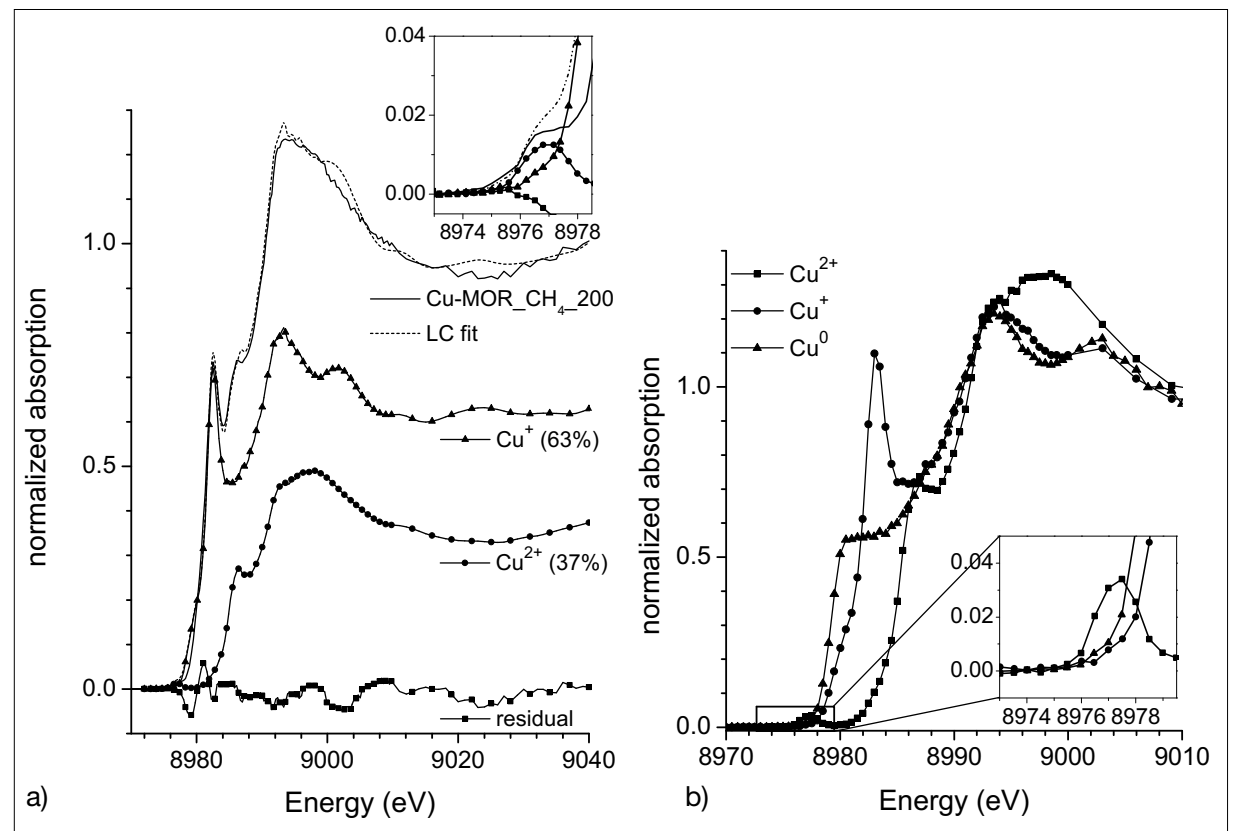

Fig. 3. (a) Linear combination fit of $\mathrm{Cu}-\mathrm{MOR}$ reacted with $\mathrm{CH}_{4}$ and the (b) reference spectra.

\section{Conclusions and Outlook}

There is clear demand for improved process technology to utilize methane for liquid fuels and chemicals. However, proposed alternative routes do not show the activity, selectivity, and stability of a catalytic system for large-scale application. Enzyme-like catalysts in the form of metal-exchanged zeolites work at low temperature and show very high selectivity to methanol but this route does not as yet allow a continuous catalytic process. Insights into the reaction mechanism and structure of the active site are vital for improving this low-temperature process route. We have shown that it is possible to operate the process in a batch-wise manner in a single reactor, which opens the possibility for catalytic operation. We have also shown insights into the structure of $\mathrm{Cu}$ sites using X-ray spectroscopy corroborating previous work. In addition, we have shown that a large fraction of $\mathrm{Cu}$ reacts upon methane interaction in contrast to the previously proposed minority of $\mathrm{Cu}$ species. The next generation of materials for low-temperature methane to liquid chemicals needs dispersed single $\mathrm{Cu}-\mathrm{O}-\mathrm{Cu}$ active sites and to allow the redox mechanism needed to activate molecular oxygen, give off the activated oxygen to methane, thereby stabilizing the intermediate. Then, the product must be released, and the catalyst goes back to the initial reduced state ready to be reactivated. The material should possess the robustness of changing local gas environments.

\section{Acknowledgments}

We thank Dr. Frank Krumeich for the TEM measurements, the Paul Scherrer Institute for the grant of beamtime at the SLS, and the colleagues who measured with us during beamtime.

Received: July 9, 2012

[1] Global Gas Flaring Report, 'Estimated flared volumes from satellite data', 2006-2010, The World Bank Group, 2011, http://go.worldbank. org/G2OAW2DKZO.

[2] A. Holmen, Catal. Today 2009, 142, 2.

[3] J. R. Webb, T. Bolano, T. B. Gunnoe, Chemsuschem 2011, 4, 37.

[4] K. Otsuka, Y. Wang, Appl. Catal. A-Gen. 2001 , $222,145$.

[5] O. V. Krylov, Catal. Today 1993, 18, 209

[6] J. A. Barbero, M. C. Alvarez, M. A. Banares, M. A. Pena, J. L. G. Fierro, Chem. Commun. 2002 , 1184.

[7] M. C. Alvarez-Galvan, N. Mota, M. Ojeda, S Rojas, R. M. Navarro, J. L. G. Fierro, Catal. Today 2011, 171, 15.

[8] N. F. Goldshleger, A. A. Shteinman, A. E Shilov, V. V. Eskova, Zh. Fiz. Khim. 1972, 46 , 1353.

[9] B. G. Hashiguchi, C. H. Höverlmann, S. M Bischof, K. S. Lokare, C. H. Leung, R. A. Periana, in 'Energy production and storage: inorganic chemical strategies for a warming 
world', Ed. R. H. Crabtree, John Wiley, Chichester, 2010, pp. 101.

[10] R. A. Periana, D. J. Taube, E. R. Evitt, D. G. Loffler, P. R. Wentrcek, G. Voss, T. Masuda, Science 1993, 259, 340.

[11] R. A. Periana, D. J. Taube, S. Gamble, H. Taube, T. Satoh, H. Fujii, Science 1998, 280, 560.

[12] R. A. Periana, O. Mironov, D. Taube, G. Bhalla, C. J. Jones, Science 2003, 301, 814.

[13] R. Palkovits, M. Antonietti, P. Kuhn, A. Thomas, F. Schüth, Angew. Chem. Int. Ed. 2009, 48, 6909.

[14] R. G. Bergman, Nature 2007, 446, 391.

[15] M. Lin, A. Sen, Nature 1994, 368, 613.

[16] G. V. Nizova, G. Suss-Fink, S. Stanislas, G. B. Shul'pin, Chem. Commun. 1998, 1885.

[17] C. G. Jia, T. Kitamura, Y. Fujiwara, Acc. Chem. Res. 2001, 34, 633

[18] S. Mukhopadhyay, A. T. Bell, Angew. Chem. Int. Ed. 2003, 42, 1019.

[19] L. J. Lobree, A. T. Bell, Ind. Eng. Chem. Res. 2001, 40, 736 .

[20] A. C. Rosenzweig, P. Nordlund, P. M. Takahara, C. A. Frederick, S. J. Lippard, Chem. Bio. 1995, 2, 409.

[21] M. Costas, K. Chen, L. Que, Coord. Chem. Rev. 2000, 200, 517.

[22] G. I. Panov, V. I. Sobolev, A. S. Kharitonov, J. Mol. Catal. 1990, 61, 85.

[23] G. I. Panov, G. A. Sheveleva, A. S. Kharitonov, V. N. Romannikov, L. A. Vostrikova, Appl. Catal. A. Gen. 1992, 82, 31.

[24] V. I. Sobolev, A. S. Kharitonov, Y. A. Paukshtis, G. I. Panov, J. Mol. Catal. 1993, 84, 117.

[25] A. Ribera, I. Arends, S. de Vries, J. PerezRamirez, R. A. Sheldon, J. Catal. 2000, 195, 287.

[26] P. Kubanek, B. Wichterlova, Z. Sobalik, J. Catal. 2002, 211, 109.

[27] K. A. Dubkov, V. I. Sobolev, E. P. Talsi, M. A Rodkin, N. H. Watkins, A. A. Shteinman, G. I. Panov, J. Mol. Catal. A Chem. 1997, 123, 155.

[28] K. A. Dubkov, V. I. Sobolev, G. I. Panov, Kinet Catal. 1998, 39, 72.

[29] S. I. Chan, S. S. F. Yu, Acc. Chem. Res. 2008 41, 969.

[30] P. P. Y. Chen, R. B. G. Yang, J. C. M. Lee, S. I. Chan, Proc. Nat. Acad. Sci. USA 2007, 104 14570 .

[31] S. I. Chan, V. C. C. Wang, J. C. H. Lai, S. S. F. Yu, P. P. Y. Chen, K. H. C. Chen, C.-L. Chen, M. K. Chan, Angew. Chem. Int. Ed. 2007, 46, 1992.

[32] P. P. Y. Chen, S. I. Chan, J. Inorg. Biochem. 2006, 100, 801 .
[33] R. L. Lieberman, A. C. Rosenzweig, Nature 2005, 434, 177.

[34] R. Balasubramanian, S. M. Smith, S. Rawat, L. A. Yatsunyk, T. L. Stemmler, A. C. Rosenzweig, Nature 2010, 465, 115.

[35] M. Iwamoto, H. Furukawa, Y. Mine, F. Uemura, S. I. Mikuriya, S. Kagawa, J. Chem. Soc. Chem. Commun. 1986, 1272.

[36] M. Iwamoto, H. Yahiro, Y. Mine, S. Kagawa, Chem. Lett. 1989, 213.

[37] M. H. Groothaert, K. Lievens, J. A. van Bokhoven, A. A. Battiston, B. M. Weckhuysen, K. Pierloot, R. A. Schoonheydt, Chemphyschem 2003, 4, 626.

[38] M. H. Groothaert, J. A. van Bokhoven, A A. Battiston, B. M. Weckhuysen, R. A. Schoonheydt, J.Am. Chem. Soc. 2003, 125, 7629

[39] M. H. Groothaert, P. J. Smeets, B. F. Sels, P. A Jacobs, R. A. Schoonheydt, J. Am. Chem. Soc. 2005, 127, 1394.

[40] J. S. Woertink, P. J. Smeets, M. H. Groothaert, M. A. Vance, B. F. Sels, R. A. Schoonheydt, E. I. Solomon, Proc. Nat. Acad. Sci. USA 2009, 106, 18908 .

[41] P. J. Smeets, M. H. Groothaert, R. M. van Teeffelen, H. Leeman, E. J. M. Hensen, R. A. Schoonheydt, J. Catal. 2007, 245, 358.

[42] E. V. Starokon, M. V. Parfenov, L. V. Pirutko, S. I. Abornev, G. I. Panov, J. Phys. Chem. C 2011, $115,2155$.

[43] N. V. Beznis, B. M. Weckhuysen, J. H. Bitter, Catal. Lett. 2010, 138, 14.

[44] E. V. Starokon, K. A. Dubkov, L. V. Pirutko, G. I. Panov, Top. Catal. 2003, 23, 137.

[45] C. Hammond, M. M. Forde, M. H. Ab Rahim, A Thetford, Q. He, R. L. Jenkins, N. Dimitratos, J. A. Lopez-Sanchez, N. F. Dummer, D. M Murphy, A. F. Carley, S. H. Taylor, D. J. Willock, E. E. Stangland, J. Kang, H. Hagen, C. J. Kiely, G. J. Hutchings, Angew. Chem. Int. Ed. 2012, 51, 5129

[46] P. J. Smeets, M. H. Groothaert, R. A. Schoonheydt, Catal. Today 2005, 110, 303.

[47] P. Vanelderen, R. G. Hadt, P. J. Smeets, E. I. Solomon, R. A. Schoonheydt, B. F. Sels, J. Catal. 2011, 284, 157.

[48] N. V. Beznis, B. M. Weckhuysen, J. H. Bitter, Catal. Lett. 2010, 136, 52.

[49] A. Itadani, Y. Kuroda, M. Nagao, Microporous Mesoporous Mater. 2004, 70, 119.
[50] Y. P. Zhang, K. M. Lee, A. F. Sarofim, Z. C. Hu, M. Flytzani-Stephanopoulos, Catal. Lett. 1995 31,75 .

[51] L. T. Tsikoza, E. V. Matus, Z. R. Ismagilov, V. A. Sazonov, V. V. Kuznetsov, Kinet. Catal. 2005, 46, 613.

[52] E. M. Alayon, M. Nachtegaal, M. Ranocchiari, J. A. van Bokhoven, Chem. Commun. 2012, 48, 404.

[53] S. C. Larsen, A. Aylor, A. T. Bell, J. A. Reimer, J. Phys. Chem. 1994, 98, 11533.

[54] C. C. Chao, J. H. Lunsford, J. Chem. Phys. 1972, 57, 2890.

[55] M. LoJacono, G. Fierro, R. Dragone, X. B. Feng, J. dItri, W. K. Hall, J. Phys. Chem. B 1997, 101, 1979.

[56] J. Dedecek, B. Wichterlova, J. Phys. Chem. 1994, $98,5721$.

[57] J. Dedecek, B. Wichterlova, J. Phys. Chem. B 1997, 101, 10233.

[58] C. Lamberti, S. Bordiga, M. Salvalaggio, G. Spoto, A. Zecchina, F. Geobaldo, G. Vlaic, M. Bellatreccia, J. Phys. Chem. B 1997, 101, 344.

[59] P. Kumashiro, Y. Kuroda, M. Nagao, J. Phys. Chem. B 1999, 103, 89.

[60] G. T. Palomino, P. Fisicaro, S. Bordiga, A Zecchina, E. Giamello, C. Lamberti, J. Phys. Chem. B 2000, 104, 4064.

[61] F. X. Llabrés i Xamena, P. Fisicaro, G. Berlier, A. Zecchina, G. Turnes Palomino, C. Prestipino, S. Bordiga, E. Giamello, C. Lamberti, J. Phys. Chem. B 2003, 107, 7036.

[62] M. H. Groothaert, K. Pierloot, A. Delabie, R. A. Schoonheydt, PCCP 2003, 5, 2135.

[63] M. H. Groothaert, K. Lievens, H. Leeman, B. M. Weckhuysen, R. A. Schoonheydt, J. Catal. 2003, 220, 500

[64] E. M. C. Alayon, M. Nachtegaal, E. Kleymenov, J. A. van Bokhoven, Microporous Mesoporous Mater. 2012, doi:10.1016/j. micromeso.2012.04.054.

[65] K. Hämäläinen, D. P. Siddons, J. B. Hastings, L. E. Berman, Phys. Rev. Lett. 1991, 67, 2850.

[66] O. V. Safonova, M. Tromp, J. A. van Bokhoven, F. M. F. de Groot, J. Evans, P. Glatzel, J. Phys. Chem. B 2006, 110, 16162 .

[67] E. Kleimenov, A. Bergamaschi, J. van Bokhoven, M. Janousch, B. Schmitt, M. Nachtegaal, J. Phys. Conf. Ser. 2009, 190, 012035.

[68] G. J. Millar, A. Canning, G. Rose, B. Wood, L. Trewartha, I. D. R. Mackinnon, J. Catal. 1999, $183,169$.

[69] J. Chaboy, A. Munoz-Paez, F. Carrera, P. Merkling, E. S. Marcos, Phys. Rev. B 2005, 71. 